\title{
ENSINO DA MEDICINA TROPICAL NOS CURSOS DE PÓS-GRADUAÇÃO *
}

\author{
Carlos da Silva Lacaz **
}

\section{INTRODUÇÃO}

Uma das finalidades do "Instituto de Medicina Tropical de São Paulo" é a de proporcionar anualmente cursos de pós-graduação em Medicina Tropical a médicos interessados em aperfeiçoar seus conhecimentos neste ramo do saber médico. o referido curso, realizado em caráter intensivo, está aberto para 25 candidatos, exigindo-se para sua freqüência, o titulo de doutor em Medicina.

Desde 1960 vimos promovendo êsses cursos, com a duração de 10 a 12 semanas, entre janeiro a março de cada ano. Para sua programação contamos com a valiosa colaboração do Dr. Raymundo Martins Castro, que já havia estagiado no Tropeninstitut, de Hamburgo, lá realizando curso semelhante.

No curso regular, de pós-graduação, tem sido dada particular ênfase à clínica de doenças infecciosas e parasitárias, em vista do abundante material disponivel em São Paulo (Hospital das Clínicas, Hospital Emílio Ribas, Departamento de Profilaxia da Lepra, Hospital do Pênfigo Foliáceo e Instituto Butantã, principalmente) .

São Paulo, por sua situação geo-econômica, drena para seus hospitais numerosos casos de "patologia tropical", através das correntes de trabalhadores oriundas das regiōes intertropicais do país. Aliás, o "Instituto de Medicina Tropical de Sãc Paulo" foi, no dizer do Prof. Aguiar Pupo, mais um argumento de progresso da terra bandeirante, que desenvolveu uma grande civilização em região intertropical, sendo digno de nota a situação de nossa metrópole industrial sôbre a linha do Trópico de Capricórnio.

No decorrer de vários anos, o "Curso de pós-graduação em Medicina Tropical" foi se adaptando às conveniências e necessidades do pessoal discente, razão precípua de sua existência. Assim sendo, vêm sendo gradativamente diminuídas as preleções teóricas, de tipo magistral e, aumentando-se cada vez mais os Seminários e as aulas de caráter prático ou teórico-prático, com a ativa participação dos alunos.

\section{PROGRAMA E DURAÇÃO DO CURSO}

O "Curso de pós-graduação em Medicina Tropical" tem, incluindo os exames finais, a duração de 11 semanas. Elle se inicia com uma preleção sôbre "Patologia tropical" e visita ao Museu de Medicina Tropical e Geografia Médica. Algumas aulas sôbre Laboratório clínico servem para recordar aos alunos os diversos processos utilizados no diagnóstico das moléstias infecciosas e parasitárias, incluindo os exames subsidiários. O Curso engloba:

a) Reuniōes para discussão clínica (com apresentação de casos)

b) Noções de Epidemiologia

c) Temas de Micologia médica

d) Temas de Virologia médica (incluindo Rickettsioses)

e) Exercicios de Imunologia e Bacteriologia

f) Temas de Bacteriologia médica

\footnotetext{
* Trabaltio apresentado ao Congresso de Sociedade Brasíleira de Medicina Tropical (Recife, Fevereiro de 1968)

- Diretor do Instituto de Medicina Tropical de São Paulo
} 
g) Prática de doentes (Hospitais das Clinicas, Hospital Emílio Ribas, Departamento de Profilaxia da Lepra, Serviço do Pênfigo Foliáceo e Instituto Butantã)

h) Terapêutica antibiótica e Quimioterảpica

i) Imunizaçōes

j) Fundamentos de Alergia

k) Temas de Protozoologia médica

1) Temas de Helmintologia médica

m) Temas de Entomologia médica

n) Doenças carenciais

o) Zoonoses

p) Animais peçonhentos

q) Seminários, com a participação de vários professôres, sôbre os seguintes temas: Imunizações, Antibióticos, Blastomicose sul-americana, Doença de Chagas, Hepatites por vírus, Esquistossomose mansônica, Tétano, Meningites, Malária e Leishmanioses

r) Visitas aos Institutos Adolfo Lutz, Biológico, Butantã, Serviço de Poliomielite e Instituto Pasteur

s) Exibição de filmes científicos.

Durante o curso, com a participação dos alunos, são realizados 2 seminários, nos quais colegas de outras naçōes discutem os principais aspectos da patologia regional de seus países.

Além de aulas teóricas, há uma parte prática, com demonstraçōes microscópicas (Microbiologia e Parasitologia) e exercícios de Sorologia e de Bacteriologia. Periòdicamente são feitas visitas ao Musen de Medicina Tropical.

\section{SELEÇAO DOS ALUNOS. APRO- VEITAMENTO}

Anualmente, o "Instituto de Medicina Tropical de São Paulo", oferece a médicos brasileiros e de outros países, principalmente da América Latina, 25 vagas. A seleção se faz através do currículo de cada candidato, levando-se em consideração, principalmente, as atividades futuras profissionais (no campo da especialidade) ou docentes dos interessados.

Cobramos atualmente uma taxa de inscrição no valor de NCr $\$ 20,00$ (vinte cruzeiros novos), e com esta importância compramos alguns livros sôbre problemas de
Patologia tropical ou assuntos afins e que são fornecidos aos alunos. Há vários anos o Laboratório Pfizer vem custeando o pagamento de 5 bôlsas a alunos selecionados pelo IMT de São Paulo. Os colegas estrangeiros geralmente procedem de seus países com bôlsas de estudo fornecidas pela OMS e OEA.

Recentemente, a Universidade de Louisiana fêz um convênio com o Instituto de Medicina Tropical de São Paulo, mediante o qual dois médicos da marinha americana são escolhidos para realizarem o referido curso, precedido de um estágio em nossos laborátórios e clínicas especializadas, durante 12 meses.

No final do curso realizam-se os exames, com a seguinte orientação:

1.0) Exame teórico-prático - Leitura de uma observação, com vários exames de laboratório, para interpretação diagnóstica.

2. ${ }^{\circ}$ Exame de um doente.

3. ${ }^{\circ}$ Exame prático de Microbiologia.

4.0) Exame prático de Parasitologia.

5..$^{\circ}$ Exame no Museu de Medicina Tropical.

6.') Exame final, sob a forma de testes, cobrindo tôda a matéria teórica.

Sòmente participam dos exames, os alunos que freqüentarem $2 / 3$ das aulas programadas. Ao aluno classificado em $10^{\circ}$ lugar, o Laboratório Carlo Erba oferece anualmente, medalha de ouro e o Instituto, para os aprovados, um diploma, assinado pelos membros integrantes do seu Conselho Administrativo.

\section{DIPLOMADOS}

De 1960 a 1968, 185 médicos realizaram, com aproveitamento, o curso de pós-graduação em Medicina Tropical, assim distribuídos:

INSTITUTO DE MEDICINA TROPICAL DE SÁo PAULO

CURSO DE PÓS-GRADUAÇÁ EM MEDICINA TROPICAL

(1960 a 1968) 
Procedência

BRASIL

Amazonas

Bahia . . ........... 8

Ceará . ............. 3

Espirito Santo . ......... 1

Goiás . . ............ 5

Guanabara . . . ....... 4

Mato Grosso . ......... 2

Minas Gerais . ......... 8

Pará . . ............. 4

Paraná . . .......... 2

Pernambuco . . . ....... 10

Rio Grande do Norte .... 1

Rio Grande do Sul ..... 4

Santa Catarina ......... 2

São Paulo . ...........

Total . . . . $13 \ldots \ldots \ldots$.

EXTERIOR

Argentina . . . . . . . $\quad 7$

Bolivia . . ........... 2

Colômbia . . ......... 5

Costa Rica . . ......... 1

Estados Unidos . ........ 2

Guatemala . . ........ 1

Iugoslávia . . . . .

Panamá . . . . . . . . 1

Paraguai . . ........... 1

Perú . . ............ 12

Venezuela . . ......... 20

Total . . . . . $54 \ldots \ldots \ldots$

Total geral

1

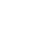

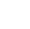

(2.20

e p

(In

(1)

(Pain

\begin{tabular}{l}
4 \\
4 \\
\hline
\end{tabular}
com a valiosa colaboração de outros institutos universitários.

Há anos, o "Instituto de Medicina Tropical de São Paulo", recebeu da "União das Universidades Latino-Americanas", com sede na Cidade do México, alta distinção, credenciando-o como centro de treinamento cientifico e docente, no campo da Medicina Tropical, para a América Latina.

Após o curso, muitos alunos permanecem em nossos laboratórios e clínicas, aperfeiçoando seus conhecimentos em um dos vários ramos da Medicina Tropical.

Esta é, indiscutivelmente, mais uma significativa colaboração da Universidade de São Paulo ao progresso cultural e científico de nossa terra e em benefício da própria humanidade. Sentimo-nos orgulhosos do que já realizamos neste setor, projetando nossa capacidade científica no próprio plano internacional. 